\title{
Oncological cosmetics formulations based on medicinal plants
}

\author{
Formulações cosméticas oncológicas baseadas em plantas medicinais \\ Formulaciones cosméticas oncológicas a base de plantas medicinales \\ Gisele Mara Silva Gonçalves ${ }^{1 *}$, Adeline Leonello da Silva ${ }^{1}$.
}

\begin{abstract}
Objective: Developing dermocosmetic formulations to minimize the harmful and/or undesirable effects of chemotherapy on the skin. Methods: Vegetable compounds with proven hydrating, emollient, antiinflammatory and antimicrobial action were selected: extracts or tinctures of Arnica montana L., Calendula officinalis L., Punica granatum and Rosmarinus officinalis L. Two formulations were proposed, cream and gelcream, evaluated for accelerated stability and preservation challenge test, with inoculation of Staphylococcus aureus, Pseudomonas aeruginosa and Escherichia coli, and evaluation for 28 days. Results: The formulations were considered adequate and the proposed objective was achieved, developing two novel formulations, a cream and a gel-cream, which can compose an innovative product line that meets the needs of the cancer patient. Conclusion: The cream formulation was proposed for epidermal cell renewal and skin moistening, containing the combination of pomegranate tincture (Punica granatum) and marigold glycolic extract (Calendula officinalis), while the gel-cream formulation has anti-inflammatory potential provided by rosemary tincture (Rosmarinus officinalis) and arnica tincture (Arnica montana). The formulations were stable, having the potential to improve the life quality of cancer patients.
\end{abstract}

Keywords: Arnica, Calendula, Pomegranate, Rosmarinus.

\section{RESUMO}

Objetivo: Desenvolver formulações dermocosméticas para minimizar os efeitos prejudiciais e/ou indesejáveis da quimioterapia na pele. Métodos: Selecionou-se compostos de origem vegetal com comprovada ação hidratante, emoliente, anti-inflamatória e antimicrobiana: extratos ou tinturas de Arnica montana L., Calendula officinalis L., Punica granatum e Rosmarinus officinalis L. Duas formulações foram propostas, creme e gel creme, avaliadas quanto a estabilidade acelerada e ao teste do desafio do conservante, com inoculação de Staphylococcus aureus, Pseudomonas aeruginosa e Escherichia coli e avaliação por 28 dias. Resultados: As formulações foram consideradas adequadas e o objetivo proposto foi atingido, desenvolvendo-se duas formulações inéditas, um creme e um gel creme, que podem compor uma linha de produtos inovadora que atenda às necessidades do paciente oncológico. Conclusão: A formulação de creme foi proposta para renovação celular epidérmica e umectação da pele, contendo a associação de tintura de romã ( $P$ unica granatum) e extrato glicólico de calêndula (Calendula officinalis), enquanto a formulação de gel-creme tem potencial anti-inflamatório proporcionado pela tintura de alecrim (Rosmarinus officinalis) e tintura de arnica (Arnica montana). As formulações foram estáveis tendo potencial para melhoria da qualidade de vida de pacientes oncológicos.

Palavras-chave: Arnica, Calendula, Romã, Rosmarinus.

\section{RESUMEN}

Objetivo: Desarrollar cosméticos para reducir los efectos nocivos no deseados de la quimioterapia en la piel. Métodos: Se utilizaron extractos o tinturas de Arnica montana L., Calendula officinalis L., Punica granatum y Rosmarinus officinalis L. con probada acción hidratante, emoliente, antiinflamatoria y antimicrobiana. Se propusieron formulaciones de crema y crema en gel, que se evaluaron para pruebas de estabilidad acelerada y efectividad de conservación, utilizando Staphylococcus aureus, Pseudomonas aeruginosa y Escherichia

${ }_{1}^{1}$ Pontifícia Universidade Católica de Campinas, Campinas - SP. *E-mail: gmsg@puc-campinas.edu.br 
coli. Resultados: Las formulaciones se consideraron adecuadas y se logró el objetivo propuesto, desarrollando dos novedosas formulaciones, una crema y una crema gel, que pueden componer una línea de productos innovadora que satisfaga las necesidades del paciente oncológico. Conclusión: La formulación en crema fue propuesta para la renovación celular epidérmica y humectación de la piel, que contiene la combinación de tintura de granada (Punica granatum) y extracto glicólico de caléndula (Calendula officinalis), mientras que la formulación crema-gel tiene potencial anti-envejecimiento. Efecto inflamatorio proporcionado por la tintura de romero (Rosmarinus officinalis) y la tintura de árnica (Arnica montana). Las formulaciones eran estables y tenían el potencial de mejorar la calidad de vida de los pacientes con cáncer.

Palabras clave: Arnica, Calendula, Granada, Rosmarinus

\section{INTRODUCTION}

Cancer is considered the second leading cause of death in the world and its numbers tend to increase, due to risk factors such as smoking, alcoholism, sedentary lifestyles and unhealthy diets, in addition to genetic factors (ORGANIZAÇÃO PAN-AMERICANA DA SAÚDE, 2018).

Treatments vary for each type of cancer and the correct diagnosis being of fundamental importance. Chemotherapy brings some undesirable effects that alter the patient's psychological and physical state, with hair loss and skin-related effects, such as xerosis, eczema, dermatitis, sensitivity to the sun, among others, which can be alleviated with the use of cosmetics, more specifically, dermocosmetics (GUIO AH, et al., 2017). The dermatological changes triggered and aggravated by chemotherapy treatment were acneiform rash, xerosis, hyperpigmentation, toxic epidermal necrolysis, hand foot syndrome, extravasation, erythema nodosum and supravenous hyperpigmentation (PAVEY RA, et al., 2015).

Given the importance of skin integrity and the fact that patients may have weakened immune systems, it is appropriate that dermocosmetics are developed to assist in hydration and skin protection, minimizing pain and side effects of treatment and disease, containing mild components, avoiding the use of irritating, teratogenic and preservative substances, free from alcohol, however, rich in essential fatty acids to provide emollience, moistening and occlusion (FRANQUILINO E, 2018).

The use of medicinal plants for various purposes is an ancient practice. In Brazil, this is greatly influenced by indigenous, African and European cultures, which complete a principle of curing the disease and restoring the individual (BADKE MR, et al., 2016). The use of active compounds of plant origin in formulations follows new principles of present-day society, which looks beyond sustainability and respect for the environment, quality, beauty, well-being and pleasure provided by its use (MIGUEL LM, 2011). For the development of cosmetics for cancer patients, the use of medicinal plants can be considered, whose secondary metabolites exert defense functions in the plant (TUNGMUNNITHUM D, et al., 2018).

A clinical study conducted in 99 diagnosed cancer patients (receiving cytotoxic chemotherapy, targeted or hormonal treatments, and / or radiotherapy) and three specially developed products (skin moisturizer, face moisturizer and face wash) showed promising results. Although the authors did not describe the composition of each product, they were well tolerated and resulted in improved skin conditions. These findings demonstrate the importance of patients receiving interventions during anticancer therapy and the immediate follow-up period of 4 months (HALEY, AC, et al, 2011).

Polyphenols, compounds naturally present in several medicinal plants, have antioxidant action and contribute to the improvement of skin health, providing softness, protection from ultraviolet radiation, favoring microcirculation and regeneration of the epidermis (MICHALAK M, et al., 2021).

Arnica montana L. has indications for topic treatment of inflammatory skin disorders (GASPAR A, 2014). Studies have shown that sesquiterpene lactones (arnicolid, helenaline and dihydro-helenaline), together with flavonoid lactones, alcohols (arnidiol, arnilenediol and isoarnylenediol), carotenoids, essential oil, phenylcarboxylic acid are some of the secondary metabolites present in Arnica montana L., and also point out that the helenaline and dihydro-helenaline ethers are the active ingredients that are most important, being responsible for the anti-inflammatory action (NASCIMENTO ED e CESARETTI MLR , 2011). 
Calendula officinalis $\mathrm{L}$. has its indications as a healing and anti-inflammatory action for skin disorders (BRASIL, 2014). Among the main chemical constituents of Calendula officinalis L., we have the essential oil, flavonoids, carotenoids, mucilages, resins, and bitter principle, however, they emphasize that flavonoids are the class with an important role in pharmacological action (JAN N, et al., 2017).

Punica granatum, pomegranate, has medicinal, antimicrobial, dental, antifungal, antioxidant, antineoplastic and chemoprotective properties (DEGASPARI CH e DUTRA AP, 2011). They stand out as the chemical compounds: flavonoids, anthocyanins, tannins, alkaloids, punic acid and ursolic acid, as important constituents of Punica granatum, and punicalagin has potent anticancer activity (BASSIRIJAHROMI S, 2018).

Rosemary or Rosmarinus officinalis L. is indicated as an antibiotic, anti-inflammatory, antioxidant and analgesic. The main constituents of Rosmarinus officinalis, polyphenolic compounds - carnosic acid, quercetin, rosmarinic acid and ursolic acid (KARADAĞ AE, et al., 2019).

The purpose of this study was to propose oncological dermocosmetic formulations aiming at hydration and smoothness, in addition to the potential for protection, emollience and pain reduction to minimize the undesirable effects of chemotherapy on the skin of cancer patients, to contribute to life quality.

\section{METHODS}

After preliminary studies, two formulations were proposed for evaluation. The first, entitled Formulation A, contained Vitis venifera seed oil 2.0\%, Benzophenone-3 3.0\%, Octyl methoxycinnamate $6.5 \%$, Salicylate 2 ethilexila 2.0\%, Calendula officinalis extract $5.0 \%$ and Punica granatum $5.0 \%$, served in non-ionic based cream (Emulsifying wax NF $6.5 \%$, BHT $0.05 \%$, EDTA $0.5 \%$, parabens blend and purified water). The second, entitled Formulation B, contained Vitis venifera seed oil $2.5 \%$, Rosmarinus officinalis 10\%, Arnica montana 10\%, served in anionic base gel (Ammonium acryloyldimethyltaurate/VP Copolymer $1.5 \%$, glycerin $4 \%$ and purified water).

Formulations $A$ and $B$ were prepared and secured in opaque, plastic packaging with a lid to ensure sealing to prevent loss of vapor to the environment. They were stored at ambient temperature, $40^{\circ} \mathrm{C}$ and $50^{\circ} \mathrm{C}$ and evaluated for physico-chemical aspects, such as preliminary test by centrifugation (centrifugation at $3200 \mathrm{rpm}$ for 30 minutes), determination of the $\mathrm{pH}$ of the samples diluted to $10 \%$ in deionized water, viscosity in viscometer Brookfield $\AA$ and organoleptic characteristics (color and odor), and the antimicrobial efficacy test was performed. They were reassessed in 24 hours, 7, 14, 21 and 28 days. All physico-chemical quality control analyzes were developed in accordance with the Cosmetic Products Stability Guide (GONÇALVES GMS, et al., 2014).

The antimicrobial efficacy test was performed based on the adaptation of the Brazilian Pharmacopeia VI (2019) and was performed in triplicate by the plate counting method, as described below.

Inoculum preparation: Strains of Staphylococcus aureus (ATCC 6538), Pseudomonas aeruginosa (ATCC 9027) and Escherichia coli (ATCC 11229) were used. The activation of the strains and their raising were performed with stretch marks on Trypticase Soy Agar (TSA); incubated in a Fanem $\AA$ oven at $35^{\circ} \mathrm{C}$ for 24 hours. These cultures were diluted in $5 \mathrm{~mL}$ of sterile saline until turbidity of tube number 0.5 on the McFarland standard.

Contamination of the formulation samples: Exactly $10 \mathrm{~g}$ of each formulation was transferred to flasks with a lid, previously sterilized and added to $200 \mu \mathrm{L}$ of the suspension of each microorganism.

Incubation and analysis of contaminated samples: The samples were incubated in a Fanem $\AA$ oven for 28 days. An aliquot was taken every 7 days to count viable microorganisms. From these aliquots, serial dilution in peptone water was performed, obtaining dilutions of $10^{-1}, 10^{-2}, 10^{-3}$ and $10^{-4}$. The dilutions were inoculated in depth in TSA and incubated at $\sim 35^{\circ} \mathrm{C}$, for subsequent counting in the number of colony-forming units (CFU) with the help of Phoenix® counter, followed by the calculation of the number of surviving microorganisms. 


\section{RESULTS}

The formulations prepared were adequate with respect to the organoleptic and physico-chemical characteristics and no phase separation was observed in the centrifugation test. The result of the preliminary stability test aims to assist and guide the choice of formulations, in addition to checking their homogeneity. Therefore, it is a test that is performed initially to assess the positive interaction of the components. The result of no phase separation indicates that the formulations are coherent and homogeneous. Formulation $A$ consisted of an opaque cream, beige and with a characteristic odor, while formulation B was a bright, orange gel-cream with a characteristic odor.

Regarding the evaluation of color and odor, only after 28 days of storage at $50^{\circ} \mathrm{C}$ a slight change in both formulations was noticed.

The $\mathrm{pH}$ values indicate there was no considerable variation during the evaluation period, even though there was a change in color and odor on the last day of analysis (Table 1). The results of apparent viscosity indicated pseudoplastic behavior and did not indicate loss of physical stability of the formulations (Figure 1). The microbiological results are described in Tables 2 and 3.

Table 1 - $\mathrm{pH}$ of formulations $\mathrm{A}$ and $\mathrm{B}$ as a function of storage time and temperature.

\begin{tabular}{lcccccc}
\hline \multirow{2}{*}{ Samples } & Storage temperature & \multicolumn{5}{c}{ Storage time (days) } \\
& & Start & $\mathbf{7}$ & $\mathbf{1 4}$ & $\mathbf{2 1}$ & $\mathbf{2 8}$ \\
\hline Diluent (deionized water) & - & 7.4 & 7.5 & 7.4 & 7.6 & 7.8 \\
\hline \multirow{2}{*}{ Formulation A } & Ambient temperature $^{*}$ & 5.6 & 5.2 & 5.3 & 5.4 & 5.5 \\
& $40^{\circ} \mathrm{C}$ & 5.5 & 5.6 & 5.5 & 5.6 & 5.5 \\
\hline Formulation B & Ambient temperature $^{*}$ & 5.6 & 5.5 & 5.8 & 5.7 & 5.3 \\
& $40^{\circ} \mathrm{C}$ & 5.5 & 5.6 & 5.8 & 5.7 & 5.2 \\
& $50^{\circ} \mathrm{C}$ & 5.4 & 5.5 & 5.8 & 5.7 & 5.2 \\
\hline
\end{tabular}

Legend: *Ambient Temp.: temperature between 25 and $29 \stackrel{\circ}{\circ} \mathrm{C}$

Source: Gonçalves GMS, et al., 2021.

Figure 1 - Apparent viscosity of formulations $A$ and $B$ as a function of increased rotation speed (red: upward curve) and subsequent reduction of rotation speed (blue: downward curve).

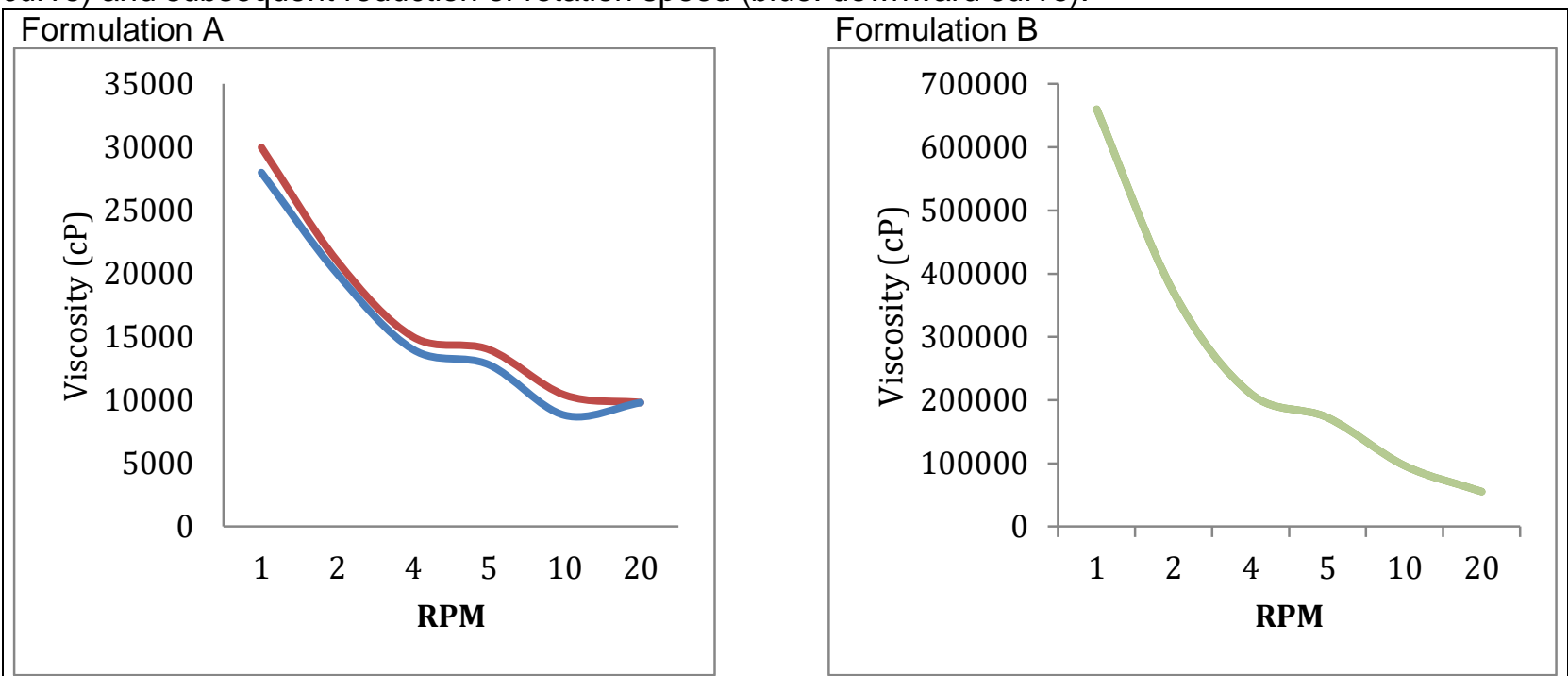

Note: The curves for formulation B overlapped, indicating absence of thixotropy.

Source: Gonçalves GMS, et al., 2021. 
Table 2 - Microbial count in formulations A and B as a function of storage time, in the antimicrobial effectiveness test.

\begin{tabular}{cccccc}
\hline \multicolumn{6}{c}{ CFU/g of formulation } \\
\hline Formulation A & Start & $\mathbf{7}^{\text {th }}$ day & $\mathbf{1 4}^{\text {th }}$ day & $\mathbf{2 1}^{\text {st }}$ day & $\mathbf{2 8}^{\text {th }}$ day \\
\hline Formulation B & 9700000 & 271000 & 420000 & 380000 & 205000 \\
\hline
\end{tabular}

Source: Gonçalves GMS, et al., 2021.

Table 3 - Logarithmic variation of the count of viable microorganisms recovered in formulations $A$ and $B$ during the antimicrobial efficacy test, depending on the incubation time of the inoculated formulation.

\begin{tabular}{ccc}
\hline & Period (days) & Logarithmic Variation \\
\hline & $01^{\text {st }} \rightarrow 07^{\text {th }}$ & +0.55 \\
& $07^{\text {th }} \rightarrow 14^{\text {th }}$ & -0.19 \\
Formulation A & $14^{\text {th }} \rightarrow 21^{\text {st }}$ & +0.05 \\
& $21^{\text {st }} \rightarrow 28^{\text {th }}$ & +0.26 \\
& $07^{\text {th }} \rightarrow 28^{\text {th }}$ & +0.67 \\
\hline $01^{\text {st }} \rightarrow 07^{\text {th }}$ & +0.08 \\
& $07^{\text {th }} \rightarrow 14^{\text {th }}$ & -0.67 \\
& $14^{\text {th }} \rightarrow 21^{\text {st }}$ & +0.18 \\
& $21^{\text {st }} \rightarrow 28^{\text {th }}$ & +0.69 \\
$07^{\text {th }} \rightarrow 28^{\text {th }}$ & +0.28 \\
\hline
\end{tabular}

Note: Positive numbers indicate a decimal reduction; negative numbers indicate an increase in microbial count.

Source: Gonçalves GMS, et al., 2021.

\section{DISCUSSION}

In this study, two formulations were developed in order to promote hydration and smoothness of the skin, in addition to presenting potential for protection, emollience and reduction of pain related to treatment, as well as low irritating potential, favoring the patient's well-being. These formulations were a cream (formulation $\mathrm{A}$ ) and a gel-cream (formulation B), both oil-in-water.

Stability study provides information on cosmetic products that indicate the degree of stability in the various conditions in which it is subjected, from manufacture to expiration. Stability can be relative, as it varies with time and has interference from internal and external factors that can accelerate or delay changes in product parameters. If the changes remained within the pre-established limits, they do not result in rejection of itself (KIM JH, et al., 2019).

Over 28 days, the stability of formulations $A$ and $B$ was tested in different ways, using three possible situations: ambient temperature, and extreme conditions of $40^{\circ} \mathrm{C}$ and $50^{\circ} \mathrm{C}$ (SMAOUI S, 2017 e GONÇALVES GMS, et al., 2014). The results demonstrate that there was no phase separation under normal storage conditions, in other words, at ambient temperature, which is expected, being considered a satisfactory result, which meets the requirements for approval.

The results obtained demonstrate that there was no change in color and odor under normal storage conditions, being considered a satisfactory result, which complies with what was established for approval. Color changes were observed in extreme conditions $\left(50^{\circ} \mathrm{C}\right)$ occurring on day 28 when the formulations $\mathrm{A}$ and $B$ were slightly modified. Organoleptic characteristics are considered extremely important parameters for the 
acceptance of the product by the consumer. Bearing this in mind, it is essential that in the analysis of these, possible changes in the products are not perceptible by the senses and do not compromise the efficacy and safety of the formulations developed.

Taking into account that under these conditions the occurrence of physico-chemical changes is frequent, it can be said that a chemical change has already been expected to result in the modification of organoleptic characteristics, such as oxidation or degradation of compounds present in the formula, of which the results obtained are acceptable, since they will not be stored in these temperature conditions for such a long period of time.

Knowing that the $\mathrm{pH}$ value is related to the possible chemical and microbiological changes in the formulation, which may affect the stability of the ingredients, efficacy and safety of the product is extremely important to make this aspect compatible so that there is a minimization of interferences. There was a constancy in the initial $\mathrm{pH}$ of the formulations, with a small variation only on the last day analysis of Formulation $\mathrm{B}$, taking into account the evaluated parameter is under normal storage conditions, that is to say, at ambient temperature, and when compared with the cutaneous pattern of 5.5 to 6.5 , demonstrating a satisfactory result, which meets what was established for approval. The evaluation of the rheological characteristics (Figure 1) is important, as it evaluates properties of the formulations such as viscosity, in this case, analyzing the deformational behavior and the flow of matter under stressers over a period of time (LOCHHEAD RY, 2017).

Viscosity is the resistance of the fluid to a shear flow, so when a fluid is subjected to a stress, its flow rate defines its viscosity. Following this concept, the different materials can be divided in two ways, relating the deformation rate and shear stress or as to the deformation. Formulations $A$ and $B$ presented pseudoplastic behavior (COSTA CM, et al., 2017).

Pseudoplastic fluids, also known as non-Newtonian behaviors, are defined by the reduction of viscosity in relation to the increase in shear force, having a reversible behavior. These will have a lower apparent viscosity the higher the applied stress, therefore, it can be interpreted that because the developed formulations present this behavior, they suffer deformation when applied, in other words, they become more fluid, facilitating the spread of the products on the skin and they recover the initial viscosity at the moment the application is finished, which prevents the products from draining, increasing the patient's acceptance. In essence, the viscosities presented by the formulations were considered suitable for application to the skin (CHIARI B, 2012).

Also known as an antimicrobial efficacy test, the purposeful contamination of the product with specific microorganisms and evaluation of the sample at defined intervals, aims to evaluate the effectiveness of the preservative system necessary to protect the product (BRAZILIAN PHARMACOPEIA VI, 2019).

Considering the approval criteria in the antimicrobial efficacy test for topical products available in the Brazilian Pharmacopeia VI (2019) for bacteria, there should be a reduction of 2 logs in the number of CFU initially inoculated, in comparison with the $14^{\text {th }}$ day, and there should be no increase in the count of the $28^{\text {th }}$ day in relation to the $14^{\text {th }}$ day. The results presented partially fit what is expected, since both formulations had a reduction of less than 2 logs in the number of CFU initially inoculated, however, there was no increase in the bacterial count of the $28^{\text {th }}$ day compared to the $14^{\text {th }}$ day. This may have occurred for two reasons: part of the microorganisms died, due to the action of the preservatives; and the other part adapted to the environment in which they were inoculated.

Taking into account the inoculum is composed of pathogenic bacteria, the development of cosmetics should be carried out using a small amount of preservatives, so that they are harmless to human health, however, being effective in preserving the product and the cancer patient, in this case (HALLA N, et al., 2018).

Thus, in the present study it is necessary to reevaluate the preservative composition used or use of packaging with a closure system that prevents the user from contact with the product and increase in chance of accidental contamination. Cosmetics need to be stored in suitable places, with mild temperature and not used after the expiration date. It is worth noting that one of the first aspects perceived by the consumer is the product and packaging as a whole, adding product value and keeping it protected with its initial characteristics (GIORGIO A, et al., 2018). 
Formulation $A$ is aimed at stimulating cell renewal and hydration, since the skin becomes fragile due to chemotherapy and the patient, in general, needs this care, also seeking topical use against skin inflammations and mucous membranes. Gel-creams, in turn, have an aqueous phase in their constitution, containing a polymer or gelling agent and an oil phase, composed of mild emollients (ALLEN JR, LOYD V, 2014). Formulation $B$ is designed to reduce pain, through an anti-inflammatory mechanism, increase local circulation, decrease eczema, and increase the healing process.

For the development of these formulations and their quality control, a lot of care and attention to a special group of patients was needed, being necessary to pay attention to the details and all the interfering factors. Odorless ingredients are important for those patients with smell disorders (AMÉZAGA J, et al., 2018 e COHEN J, et al., 2016).

Formulations A and B were composed of inputs from medicinal plants with proven effects, being regarded a medicinal plant that contains in some of its organs substances that can be used for therapeutic purposes or that are precursors to the synthesis of useful drugs (SOFOWORA A, et al., 2013).

Taking this definition into account, some medicinal plants were chosen to meet the needs, which deal with dermatological changes caused and aggravated by chemotherapy treatment, respectively, mainly cutaneous xerosis, hyperchromia, onychomycosis, erysipelas, prurigo, dermatitis, paronychia and pityriasis.

In this study, the elaborated cream formulation was mainly aimed at stimulating cell renewal and hydration due to chemotherapy treatment, thus having an association of pomegranate tincture (Punica granatum) and marigold glycolic extract (Calendula officinalis). The concentrations used of the tincture and extract were based on data from the literature that prove the effectiveness of the action.

Punica granatum, or popularly known as Pomegranate, is a widely used plant, although it is not originally from Brazil. Its most important activities are the antimicrobial, anti-inflammatory and antioxidant action. A widely used phytotherapic form is its oil, which helps in cell regeneration and proliferation, having a high hydrating content. Its dry extract has antioxidant and skin lightening action. Essentially, its main actions are scientifically proven through in vivo and in vitro studies (SOUSA, NCF, et al., 2018).

Calendula, or scientifically called Calendula officinalis, is considered a cosmopolitan plant, being cultivated worldwide. This plant has important therapeutic applications, scientifically proven by in vivo and in vitro studies, such as: humectant, anti-inflammatory, healing, anti-tumor activity, immunomodulatory activity, antimycotic (CITADINI-ZANETTE V, et al., 2012).

In the study, the elaborated gel-cream formulation was mainly intended to decrease pain, through an antiinflammatory mechanism provided by the tincture of Rosemary (Rosmarinus officinalis) and tincture of Arnica (Arnica montana). The concentrations used of the tinctures were based on data from the literature that prove the effectiveness of the action.

Widely used as an aromatic herb, rosemary, Rosmarinus officinalis, is a plant that has several studies in literature that prove its effectiveness in vivo and in vitro, however, there are few studies on humans. It acts as a good antioxidant, anti-tumor and anti-inflammatory (OLIVEIRA JCA, DA SILVA VEIGA R, 2019). This plant is also indicated for local topical use, as a healing, antimicrobial and scalp stimulant.

The popular arnica, Arnica montana, has been known for centuries and its tincture is widely used as an empirical medicine for the treatment of bruises and scarring. It should be noted that the extracts have properties in the absorption of edema and healing, as well as analgesics, anti-inflammatory and antimicrobial effects (KRIPLANI P, et al, 2017).

Bearing this in mind and emphasizing that these are unpublished products, with no records of the association of these active principles in the consulted literature, this study brought two innovative products: a cream designed to stimulate cell renewal and hydration and a gel-cream designed to decrease pain and healing. 


\section{CONCLUSION}

Formulations $A$ and $B$ were stable during the study period, with organoleptic characteristics suitable for use. In the antimicrobial efficacy test, the results revealed that the preservation of the formulations was not completely effective when submitted to purposeful inoculation, having packaging avoid direct contact of the user with the formulations to solve this condition being necessary. In the development of cosmetics for cancer patients is important considering the possibility of increased skin hydration, anti-inflammatory effect, pain reduction and restoring the skin barrier, in order to contribute to improving the life quality of patients.

\section{REFERÊNCIAS}

1. ADKE MR, et al. Saber popular: uso de plantas medicinais como forma terapêutica no cuidado à saúde. Revista de Enfermagem da UFSM. 2016; 6(2): 225-234.

2. ALLEN JR, LOYD V. Basics of compounding: tips and hints, Part 3: compounding with ointments, creams, pastes, gels, and gel-creams. International Journal of Pharmaceutical Compounding. 2014; 18(3): 228-230.

3. AMÉZAGA J, et al. Assessing taste and smell alterations in cancer patients undergoing chemotherapy according to treatment. Supportive Care in Cancer. 2018; 26(12): 4077-4086.

4. BADKE MR, et al. Saber popular: uso de plantas medicinais como forma terapêutica no cuidado à saúde. Revista de Enfermagem da UFSM. 2016; 6(2): 225- 234.

5. BASSIRI-JAHROMI S. Punica granatum (Pomegranate) activity in health promotion and cancer prevention. Oncology reviews. 2018, 12(1).

6. BRASIL. Aqência Nacional de Vigilância Sanitária. Comissão da Farmacopeia Brasileira. Formulário Nacional da Farmacopeia Brasileira. vol.1, 6 ed. Brasília: ANVISA, 2019.

7. BRASIL. Ministério da Saúde e Agência Nacional de Vigilância Sanitária. Monografia da Espécie Calendula officinalis L. (CALÊNDULA). Brasília, 2014.

8. BRASIL. Ministério da Saúde - MS. Câncer: o que é, causas, tipos, sintomas, tratamentos, diagnóstico e prevenção.

9. BRASIL. Ministério da Saúde - MS. Agência Nacional de Vigilância Sanitária - ANVISA. FARMACOPEIA BRASILEIRA 6 ed. 2019.

10. CHIARI BG, et al. Cosmetics' quality control. Latest research into quality control. 2012; 337-364.

11. CITADINI-ZANETTE V, et al.. Calendula officinalis L. (ASTERACEAE): Aspectos Botânicos, ecológicos e usos. Visão Acadêmica. 2012; 13(1).

12. COHEN J, et al. Smell and taste disorders resulting from cancer and chemotherapy. Current Pharmaceutical Design. 2016; 22(15): 2253-2263.

13. COSTA CM, et al. Caracterização reológica de fluidos complexos. Revista Brasileira de Iniciação Científica. 2017; 4(7).

14. DEGASPARI CH, DUTRA AP. Propriedades fitoterápicas da romã (Punica granatum L.). Visão Acadêmica. 2011; 12(1)

15. FRANQUILINO E. Cosméticos para Pacientes Oncológicos. Revista Cosmetics \& Toiletries Brasil. 2018; 30(1): 19-21.

16. GASPAR A, et al. Antioxidant and anti-inflammatory properties of active compounds from Arnica Montana $L$. Romanian Biotechnological Letter. 2014; 19(3): 9353-9365.

17. GIORGIO A, et al. Microbiological stability of cosmetics by using challenge test procedure. Journal of Pure and Applied Microbiology. 2018; 12(1): 23-28.

18. GONCALVES GMS, et al. Use of Curcuma longa in cosmetics: extraction of curcuminoid pigments, development of formulations, and in vitro skin permeation studies. Brazilian Journal of Pharmaceutical Sciences. 2014; 50(4): 885-893.

19. GUIO AH, et al Cuidados de la piel tras el tratamiento oncológico. FarmaJournal. 2017; 2(2): 127-136.

20. HALEY, AC, et al. Skin care management in cancer patients: an evaluation of quality of life and tolerability. Supportive Care in Cancer. 2011; (19)4: 545-554.

21. HALLA N, et al. Cosmetics preservation: a review on present strategies. Molecules. 2018; 23(7): 1571.

22. JAN N, et al. Calendula officinalis-an important medicinal plant with potential biological properties. The Proceedings of the National Academy of Sciences, India. 2017; 83: 769-787.

23. KARADAG AE, et al. In vitro antibacterial, antioxidant, anti-inflammatory and analgesic evaluation of Rosmarinus officinalis $L$. flower extract fractions. South African Journal of Botany. 2019; 125: 214-220.

24. KIM JH, et al. Global Comparison of Stability Testing Parameters and Testing Methods for Finished Herbal Products. Evidence-Based Complementary and Alternative Medicine.2019; 2019.

25. KRIPLANI P, et al. Arnica montana L.-a plant of healing. Journal of Pharmacy and Pharmacology. 2017; 69(8): 925-945.

26. LOCHHEAD RY. The use of polymers in cosmetic products. Cosmetic Science and Technology: Theoretical Principles and Applications. 2017; 171-221.

27. MIGUEL LM. Tendências do uso de produtos naturais nas indústrias de cosméticos da França. Revista Geográfica de América Central. 2011; 2:1-15.

28. MICHALAK M, et al. Bioactive Compounds for Skin Health: A Review. Nutrients. 2021; 13(1): 203-234.

29. OLIVEIRA JCA, DA SILVA VEIGA R. Impacto do uso do alecrim-Rosmarinus officinalis L.-para a saúde humana. Brazilian Journal of Natural Sciences. 2019; 2(1): 1-7.

30. ORGANIZACÃ̃ PAN-AMERICANA DA SAÚDE. Folha Informativa - Câncer. 2018.

31. PAVEY RA, et al. Dermatological adverse reactions to cancer chemotherapy. Indian Journal of Dermatology, Venereology, and Leprology. 2015; 81(4): 434.

32. SMAOUI $S$, et al. Development and stability studies of sunscreen cream formulations containing three photo-protective filters. Arabian Journal of Chemistry. 2017; 10: S1216-S1222.

33. SOFOWORA A, et al. The role and place of medicinal plants in the strategies for disease prevention. African Journal of Traditional, Complementary and Alternative Medicines. 2013; 10(5): 210-229.

34. SOUSA NCF, et al. Propriedades farmacológicas de Punica granatum $L$ (romã): uma revisão de literatura. Revista Ceuma Perspectivas. 2018; 31(1): 57-67.

35. TUNGMUNNITHUM D, et al. Flavonoids and Other Phenolic Compounds from Medicinal Plants for Pharmaceutical and Medical Aspects: An Overview. Medicines. 2018; 5(3): 93. 